\title{
Resisting Change: Erwin Guido Kolbenheyer and 'Sudeten German' Identity in West Germany after the Second World War
}

\section{Guy Tourlamain}

\section{(2) OpenEdition \\ Journals}

Electronic version

URL: http://journals.openedition.org/transtexts/262

DOI: $10.4000 /$ transtexts.262

ISSN: 2105-2549

Publisher

Gregory B. Lee

\section{Printed version}

Date of publication: 1 December 2008

Number of pages: 130-145

ISSN: 1771-2084

\section{Electronic reference}

Guy Tourlamain, « Resisting Change: Erwin Guido Kolbenheyer and 'Sudeten German' Identity in West Germany after the Second World War », Transtext(e)s Transcultures 跨文本跨文化 [Online], 4 | 2008, Online since 15 October 2009, connection on 24 April 2019. URL : http://journals.openedition.org/ transtexts/262 ; DOI : 10.4000/transtexts.262 


\title{
Resisting Change: Erwin Guido Kolbenheyer and 'Sudeten German' Identity in West Germany after the Second World War
}

\author{
GUY TOURLAMAIN
}

\begin{abstract}
This article examines the interface between the expellee experience and völkischnationalist literature in Germany between 1945 and ca. 1960, concentrating particularly on Kolbenheyer and the Sudeten Germans. In this context, post-war Germany highlights a number of angles from which to approach 'culture in transit'. I will consider völkisch-nationalist responses to temporal cultural transition in the 1950s. During this decade, Germans gradually moved away from the values and customs of a society socialised by the Nazis towards a liberal, democratic culture that sought to integrate the disparate elements left in the debris after the Second World War. I will also discuss the geographic movement of culture with the refugees from the Czech territories. I finally suggest that Sudeten German culture and identity were transformed by the experience of transit itself after 1945 .
\end{abstract}

\section{Introduction}

On 10 $10^{\text {th }}$ December 1999 the Süddeutsche Zeitung reported that Roland Brich, a member of Bavaria's ruling party, the CSU, and town councillor responsible for cultural affairs in Geretsried, had praised Hitler for having done some 'good' given the conditions of his time. Chancellor Schröder, he stated, would have been "happy to have a man like him [Hitler]" to help combat Germany's rising unemployment at the end of the twentieth century. His comments were made in the context of a long 
running debate in Geretsried over whether to rename the street named after the nationalist writer Erwin Guido Kolbenheyer, a Sudeten German resident of the town from the end of the Second World War to his death in $1962 .{ }^{1}$

This provincial political controversy in Bavaria highlights the difficulty of dealing with the Nazi past in Germany. It illustrates a profound tension that already characterised the culture of the Federal Republic of Germany (FRG) in the 1950s. The need to address the history of the Third Reich confronted efforts to avoid a past that raised uncomfortable questions of individual and collective responsibility, as well as demands for recognition from large groups of ethnic Germans expelled from Eastern Europe in the 1940s. Geretsried, which now has a population of almost 25,000 people, lies thirty-five kilometres south of Munich. It is one of the socalled Vertriebenenstädter (refugee towns) established on the sites of former munitions factories to house ethnic Germans expelled from their Eastern European homelands after the Second World War. The CSU opposed changing the name of Kolbenheyer-Straße for fear of antagonising the town's Sudeten German voters. In spite of material and social integration into the FRG, regional identity and community loyalties transferred from Czechoslovakia remain important for those who lost their homes in the post-war reorganisation of European populations, and many of their descendents.

This article examines the interface between the expellee experience and völkischnationalist literature in Germany between 1945 and ca. 1960, concentrating particularly on Kolbenheyer and the Sudeten Germans. In this context, post-war Germany highlights a number of angles from which to approach 'culture in transit'. I will consider völkisch-nationalist responses to temporal cultural transition in the 1950s. During this decade, Germans gradually moved away from the values and customs of a society socialised by the Nazis towards a liberal, democratic culture that sought to integrate the disparate elements left in the debris after the Second World War. I will also discuss the geographic movement of culture with the refugees from the Czech territories. I would like to suggest that Sudeten German culture and identity were transformed by the experience of transit itself after 1945.

\section{Cultural transition in post-war Germany}

The forced relocation of Germans from the East was agreed by the leaders of the USA, the USSR and Great Britain in Potsdam between 17th July and $2^{\text {nd }}$ August 1945,

\footnotetext{
1 'Kulturreferent stolpert über Nazi-Dichter' in Süddeutsche Zeitung, 10.12.1999. The newspaper failed to inform readers of the new name. The debate over the name of Kolbenheyer-Straße had been ongoing for over a decade, demonstrated by 'Des Dichters Erbe lastet auf der Stadt' in Süddeutsche Zeitung, 26.1.1989.
} 
although many had already begun to flee the advancing Soviet forces in the final months of the War. In all an estimated fourteen million Germans were forced to leave their homes during the final years of the War and in the months following Germany's defeat. Around two million are thought to have died before reaching their final destinations. The majority settled in the western occupation zones that, in 1949, became the FRG. For many expellees the question of German guilt under the Nazis was superseded by the memory of their own wartime suffering and the challenges they faced in building new lives in West Germany.

Their sense of having been victims of the War found substantiation in the works of völkisch-nationalist writers like Kolbenheyer. Following the confiscation by the American occupation authorities of his villa near Munich and the loss of his house in Karlsbad, (renamed Karlovy Vary by the Czech authorities) in 1945 Kolbenheyer too sought refuge in Geretsried. Although he had been living in Germany for many years, after the War he identified his fate with that of the expellees, providing an expression of their grievances and the idea of German wartime suffering as a whole in his work. ${ }^{2}$ At the same time, Kolbenheyer's contacts with fellow völkischnationalists, for example Hans Grimm, provided a bridge between Sudeten German national feeling and those on the German right who had not experienced expulsion. Together they sought to revive a nationalist ideology as the basis for a new Germany that would once again include Austria and the lost territories in the East. Their efforts to claim continued legitimacy for their racial-nationalist worldview and to distance themselves from National Socialism were juxtaposed with their attempts to relativise the history of the Third Reich. ${ }^{3}$ They blamed the Allied occupation powers for Germany's situation and the suffering of her population during and after the War. The 'denazification' and 're-education' programmes, as well as alleged attempts to impose foreign, particularly American, culture on the Germans, were considered part of yet another chapter in a long tradition of British and American oppression of Germany. This resentment had already found expression in earlier völkisch-nationalist literature, particularly during the interwar years in response to the Versailles Treaty. ${ }^{4}$

\footnotetext{
2 Wilhelm Pleyer, Hans Grimm, E.G. Kolbenheyer, Will Vesper. Gedenkrede, Munich \& Stuttgart, 1962, p. 11.

3 Hans Grimm's Warum - Woher - Aber Wohin? (Lippoldsberg, 1954) provides one of the best-selling apologies for Hitler in the post-war years. Grimm was also involved in campaigns for the release of Hitler's former deputy Rudolf Heß from prison, and maintained contact with the wives of Heß and Wilhelm Frick after the War. See, for example, Grimm's letter to Prof. Julius Heuser in New York of 24.8.1947 in DLA: Grimm to Heuser, 1935-1959; also Grimm to Kolbenheyer 4.9.1950 in DLA: Grimm to Kolbenheyer, 1933-1959.

${ }^{4}$ Hans Grimm, Volk ohne Raum, Munich 1926; Hans Grimm, Englische Rede: Wie ich den Engländer sehe, Gütersloh, 1938. Also Paul Alverdes, “Tagebuch in dieser Zeit: I. Der Reisegefährte, 29th September '39'“ in Das innere Reich, November 1939, Jahrgang 6, 2. Halbjahr, pp. 799-805.
} 
It was also picked up by the interest groups and organisations that quickly formed to represent the expellees in post-war West Germany. By cultivating German customs from Eastern Europe, they not only ensured that the cultural practices of ethnic German communities in Eastern Europe were retained for their descendents, but also maintained a memory of the suffering and injustice of the expulsions. The identity of their members was no longer characterised by regional origins alone, but also by the idea of a lost homeland or Heimat. The economic recovery that in many ways defined the early years of the Federal Republic enabled the relatively swift material integration of the expellees into West German society. ${ }^{5}$ At the same time, a wide-reaching desire among the German population to avoid confronting the difficult legacy of Nazi Germany enabled expellees to nurture a sense of grievance and suffering that was unconnected to its Nazi causes.

The 1950s saw the establishment and consolidation of the democratic state: in 1950 only one in two Germans was in favour of a multi-party system; by 1960, 79 per cent were in favour and 74 per cent believed democracy to be the best form of government. 6 Nonetheless, these figures also show that acceptance of parliamentary democracy did not emerge overnight, but occurred over a decade. And even in 1960, 26 per cent of the population apparently still had doubts about the West German system. ${ }^{7}$

Culturally too, the relationship between the German population and the post-Nazi order remained ambivalent throughout the 1950s. Garbe observes that the efforts to confront the Nazi past in the post-war period were not carried out with broad popular support. Instead, a political and intellectual elite supported by the occupation powers pursued a cultural programme that antagonised many Germans. ${ }^{8}$ This elite was composed to a large degree of those returning from exile and victims of Nazi racial and political persecution. The former were unpopular for having left while others stayed and suffered the hardships of war; the latter represented living reminders of Nazi atrocities many preferred to forget. In spite of

\footnotetext{
5 See Everhard Holtmann, 'Flüchtline in den 50er Jahren: Aspekte ihrer gesellschaftlichen und politischen Integration' in Axel Schildt \& Arnold Sywottek [eds.], Modernisierung im Wiederaufbau. Die westdeutsche Gesellschaft der 50er Jahre, Bonn, 1993, pp. 349-361.

6 Holtmann, p. 350.

7 See also: Anthony J. Nicholls, The Bonn Republic: West German Democracy, 1945-1990, London \& New York, 1997, p.11.

8 Detlef Garbe, 'Äußerliche Abkehr, Erinnerungsverweigerung und "Vergangenheitsbewältigung": Der Umgang mit dem Nationalsozialismus in der frühen Bundesrepublik' in Axel Schildt and Arnold Sywottek [eds.], Modernisierung im Wiederaufbau. Die westdeutsche Gesellschaft der 50er Jahre, Bonn, 1993, pp. 698-699.
} 
initial support for their efforts among the mainstream political parties of the new FRG, their concern to confront the recent past was quickly superseded by the need to deal with the immediate consequences of the War. Germany's military collapse, the need to provide for refugees and displaced people, and the lack of housing and food had already been evident before the end of the war. Many Germans therefore blamed them on the Allied powers, looking back on the peacetime years under the Nazis as better times. ${ }^{9}$

Experiences of suffering rather than guilt were, therefore, common in the population at large. The völkisch-nationalist message of racial and national rebirth presented the post-war population, socialised under the Nazis, with a familiar cultural option. It emphasised the common national heritage of the dislocated population and recognised the hardships the German people had experienced as a result of the War. Reacting to the official anti-Nazi rhetoric of the occupying powers, Kolbenheyer and his colleagues consciously sought to provide a framework for a new cultural identity based on völkisch-nationalism. At the same time they emphasised their anti-Soviet position, a sentiment shared by an overriding majority of Germans, and nurtured an ideal of Heimat based on an implicitly racial definition of the German nation.

\section{Heimat and Nation}

Language, Detlef Garbe tells us, is the 'social memory' of a people. ${ }^{10}$ After the Second World War, the Germans faced the task of putting the events of the Third Reich into words. Their need to express the extent of the German 'catastrophe' was accompanied by the emergence of vocabulary that described the post-war situation and its relationship to the immediate past. Peter Reichel has pointed out that Vergangenheitsbewältigung (overcoming the past) suggested that the impossible was possible, that the events of recent history could be overcome and made insignificant. ${ }^{11}$ Similarly, Wiedergutmachung (often translated in terms of paying compensation) provided a concept that allowed for the possibility that freedom from 'collective guilt' could be purchased through compensation to victims. 'Collective guilt' was itself an idea introduced by the Allied occupation powers to conceptualise German culpability for the Second World War and the crimes of the Third Reich. It was applied both in moral terms and legally, in both cases meeting

\footnotetext{
9 Garbe, pp.698-699.

10 Garbe, p. 693.

11 Peter Reichel, Vergangenheitsbewältigung in Deutschland. Die Auseinandersetzung mit der NS-Diktatur von 1945 bis heute, Munich, 2001, Chapter one.
} 
resistance. ${ }^{12}$

While the terms connected to the question of guilt and confrontation of the Nazi past were viewed by many as inventions of the Allied occupying powers, discussions of the early years of the FRG are also incomplete without reference to the 'economic miracle' and 'reconstruction', descriptors of the modernisation of society between 1945 and 1960. In terms of structural and cultural criticism, a final concept is also applicable: 'restoration', denoting the continuities with the Nazi state that have been observed in the post-war era not only among the civil service and state functionaries, but also in the largely dormant attitudes of large sectors of the population. ${ }^{13}$ The often contradictory concepts that emerged after the War therefore suggest that several simultaneous processes were at work in West Germany: reluctant, formal confrontation of the immediate past on the one hand; and a determination to concentrate on reconstruction, economic revival and restoring German pride on the other. The latter increasingly characterised 1950s West Germany and bred a climate of avoidance regarding the history of the Third Reich.

This may explain why the word Volk has not been the subject of greater discussion since the Second World War. Still used today when speaking of 'a people', for example the German people, in the context of German nationalism and particularly the Third Reich, Volk can also be translated into English as 'race'. Even allowing for the evolution of meaning over time, the term still retains racial connotations. Until 2000 the German understanding of nationality, enshrined in a nationality law dating back to 1914, was based on the 'law of the blood' (ius sanguinis) according to which citizenship was based on ancestry rather than place of birth. ${ }^{14}$ Efforts to change the immigration and naturalization laws in the last ten years have encountered considerable resistance in some conservative circles. Germany, it has been argued, has never been a land of immigrants. ${ }^{15}$ Yet, while the expellee groups reject the idea that they were immigrants, pointing out that their members were German citizens at the time of the expulsions, the Federal Republic has a wellestablished tradition of integrating migrants that goes back to its foundation and the need to deal with the Eastern European refugees. ${ }^{16}$ The expellees were

\footnotetext{
12 Reichel.

13 Holtmann, 'Flüchtlinge in den 50er Jahren,' p. 349.

14 Elizabeth Boa and Rachel Palfreyman, Heimat, a German Dream: Regional Loyalties and National Identity

in German Culture, 1890-1990, Oxford, 2000, p. 20.

15 For articles reporting the ongoing debate between 2000 and 2002, which was resumed again in 2005, see e.g.: 'Bayern bei den Green Cards Spitze' in Der Spiegel, 25.03.2002; 'Karlsruhe gebt Gegnern Recht' in Der Spiegel, 18.12.2002.

16 See 'Sudetendeutsche schimpfen über Türken-Vergleich' in Der Spiegel, 18.3.2008.
} 
considered members of the Volk. This did not, however, change their situation in material terms, or alleviate the initial tensions between the newcomers and the established population.

The cultural integration of many expellees was slowed down by the lack of a formal peace treaty after the Second World War. This meant that Germany's eastern borders were not settled until reunification in 1991, fuelling the hope that the expellees might one day return to their former homes. Furthermore, the post-war division of Germany between Soviet and Western occupying powers and the officially provisional nature of the FRG also contributed to the impression that the post-War arrangements in Germany and Eastern Europe were temporary. ${ }^{17}$ Even now, organisations representing the expellees continue to promote the idea of a 'right to a homeland' as a basic human right. ${ }^{18}$ This concept first emerged in the first half of the twentieth century as ideas of national self-determination encouraged the formation of nation-states in the place of multinational empires. In Germany, it has been upheld mainly in expellee circles. Their failure thus far to gain international recognition for the right to Heimat as a basic human right is, Andrea Bastian points out, partly the result of the lack of precision of the term itself: the expellees demand not the right to a Heimat, but the right to a specific, inherited and now lost Heimat. 19

After the Second World War, the idea of Heimat became intricately intertwined with German suffering, particularly in right-wing circles. This was not only related to the lost Heimat of the expellees, but also, for example, to the destruction of the German Heimat as a result of the bombing of cities. The theme became another area in which expellees' experiences could be linked in völkisch-nationalist discourse to the experience of the whole German nation. The difficulties of defining the term itself are highlighted by Boa and Palfreyman: "The core meaning of the word 'Heimat", its denotation, is 'home' in the sense of a place rather than a dwelling, but [...] it bears many connotations, drawing together associations no single English word could convey." 20 They therefore provide an examination of "the discourse of Heimat as a mode of reflection and commentary on the discontinuous history of

\footnotetext{
17 That the state was temporary was endorsed officially by designating Bonn the 'seat of government' rather than capital and the West German constitution the 'Basic Law'. The 'Basic Law' was also, from the West German point of view, formally valid for a united Germany.

18 See the charter of the Bund der Vertriebenen: www.bund-der-vertriebenen.de/derbdv/charta-dt.php3 [accessed on 23.6.2008]; Hans Henning Hahn, 'Wo ist Ihre Heimat?' in Spiegel Special - Die Flucht der Deutschen, Hamburg, 2002, pp. 68-72.

19 Andrea Bastian, Der Heimat-Begriff. Eine begriffsgeschichtliche Untersuchung in verschiedenen Funktionsbereichen der deutschen Sprache, Tübingen, 1995, pp. 105-106.

20 Boa and Palfreyman, p. 1.
} 
Germany in the twentieth century" 21 and the way in which this discourse has informed German identity. They suggest that the difficulties in translation have their roots in German history throughout the modern period, as Germany has gone from being a collection of individual states and principalities to a united nationstate.

The term Heimat conveys both inclusion and exclusion, as the unification of Germany under Bismarck both united and excluded Germans from the nation-state. It also highlights the tension in German nationalism between region and nation, which emerged alongside the rapid industrialization and urbanization that transformed German society in the second half of the nineteenth century. ${ }^{22}$ In the 1920s and 1930s, the idea of Heimat was increasingly connected to the myth of the nation. ${ }^{23}$ Hans Grimm's best-selling völkisch novel, Volk ohne Raum, provides an example of this transformation from regional to national identity. Here Grimm proposed colonial expansion as the solution to the alienation of a people severed from their native soil through industrial progress, population growth and the destruction of traditional social structures. ${ }^{24}$ German Heimat, according to Grimm, could be created by Germans in Africa through working the soil and settling the land. ${ }^{25}$

After the Second World War Heimat again played an important role in German culture, most notably in the escapist Heimat films that saw their heyday in German cinemas in the 1950s, reflecting popular unwillingness to address the challenges of the Nazi past. ${ }^{26}$ Over three hundred were made, presenting sentimental idylls, an unspoken mirror of Nazi ideas of the peasant as the backbone of the German race. This idyllic world was frequently broken by the arrival of an outsider, whose integration or exclusion - depending on whether he or she was a hero or villain would herald the return to social cohesion and provide a happy ending. Thus, the old question of belonging remained central to the idea of Heimat. ${ }^{27}$

Nonetheless, tension between region and nation was once again evident in the ideas of Heimat of the post-war era. On the one hand, a regional, rural identification of Heimat emerged, for example in the identification of expellees with their lost personal Heimat. On the other hand, their sense of grievance at this loss was also

\footnotetext{
21 Boa and Palfreyman, p. 29.

22 Boa and Palfreyman, p. 1.

${ }_{23}$ Boa and Palfreyman, pp. 3-4.

${ }^{24}$ Hans Grimm, Volk ohne Raum, Lippoldsberg, 1956 [First published: Munich, 1926].

25 See Hans Grimm, Volk ohne Raum, 'Part Three: „Deutscher Raum“'; also Boa and Palfreyman, pp. 5-6.

26 Boa and Palfreman, p.10.

27 Boa and Palfreman, pp.10-11.
} 
manifested in resentment at the division of the national Heimat. ${ }^{28}$ This tension was evident in the works of völkisch-nationalists, particularly those of writers like Wilhelm Pleyer and Kolbenheyer who came from the lost Eastern territories. Tobias Weger argues that the Sudeten German organisations of these years were not the product of the expulsion from the Czech territories after the war, but part of the longer struggle waged by Sudeten Germans against the Czechs before the War and the annexation of the Sudetenland by the Nazis. ${ }^{29}$ The expulsions nonetheless added a new tone to the discourse on Sudeten German Heimat in the FRG: the lost Heimat gained an emotional significance that has in many ways determined the Sudeten German identity and that of expellees from other Eastern European regions since the war.

\section{Kolbenheyer and the 'Sudetenland'}

Throughout his adult life in Austria and Germany, Kolbenheyer always maintained links with his Sudeten Heimat, particularly his mother's native city of Karlsbad. After 1945, he provided expellees with a cultural bridge between their old homelands and their new existences in West Germany. In return, expellees gave Kolbenheyer both moral and material support, providing a base from which he fought accusations of complicity with the Nazi regime that seriously affected his livelihood. On receiving a 'certificate of honour' from one branch of the Sudetendeutsche Landsmannschaft in 1952, he thanked his fellow Sudeten Germans, promising: "I will remain true to you, as you have been true to me through a time in which I was open to attack from anyone. I celebrate loyalty to the Heimat - Heil Sudetenland!" 30

Kolbenheyer reflected on his relationship with his lost Karlsbad Heimat towards the end of the third and final volume of his autobiographical novel Sebastian Karst, published in 1958. He described the town in terms he also used for his mother: "[...] for me it became a giving mother, generous-hearted and calm." ${ }^{31}$ In adult years, he added that he had experienced the city's pride in his success as he had once experienced his mother's pride in his achievements. The city was a sanctuary to which he returned each summer to find peace and rest. He described the simple accommodation of his family home - lost after 1945 - where he had enjoyed the

\footnotetext{
28 Boa and Palfreman, pp.10-11.

29 Tobias Weger, "Volkstumskampf" ohne Ende? Sudetendeutsche Organisationen, 1945-1955, Frankfurt am Main, 2008.

30 'Heil Sudetenland' in Deutsche Tagespost, 12.01.1952.

31 Erwin Guido Kolbenheyer, Sebastian Karst. Über sein Leben und seine Zeit, Vol. III., Gartenberg bei Wolfratshausen, 1958, pp. 381.
} 
company of his family and old acquaintances. His Heimat was, he stated, the place in which he was truly at home. Kolbenheyer expressed this in terms of security and familiarity:

"When I arrived in Karlsbad I was welcomed by everyone as though they had long been expecting me. When the holiday was over and I was leaving [...] they bid me farewell until the next time in the Heimat, as if, in the meantime, I was just going on an extended journey." ${ }^{32}$

This home also extended beyond the domestic sphere to encompass Kolbenheyer's national Heimat. His parents were buried, he recalled, in the high graveyard from which one could see far beyond the Eger Valley to the Erz Mountains in the German Reich, to which he felt Karlsbad by rights belonged. Thus Kolbenheyer's Heimat corresponded with the characteristics identified by Boa and Palfreyman as emerging during the First World War when:

"Heimat $[\ldots]$ was $[\ldots]$ gendered as a place of security associated with the mother and the sweetheart back at home in contrast to the Fatherland for which men fight and die in foreign fields. No longer antagonistically set over against each other, Fatherland and maternal Heimat increasingly coalesced in the myth of nation and were both set in opposition to the foreign foe or the enemy within." ${ }^{33}$

This marriage of the domestic and the national continued in Kolbenheyer's descriptions of life in post-war Germany. He opened the third volume of Sebastian Karst with a description of Christmas 1946 and the Sudeten German Christmas crib that had been in his family for several hundred years. Having been rescued from plunder, it provided a material link between Kolbenheyer and his ancestral hometown. He created the image of a traditional German hearth and home. Returning to familiar völkisch-nationalist themes of Heimat, nature and landscape, Volk, nation and suffering, he placed an emphasis on domestic details and the traditional, simple ways of life confronted by the injustices and hardships of the time in which they were living. These hardships, mirrored in the hard conditions of the winter landscape, were both particular and general: the separation from loved ones that he described was far from unique to Kolbenheyer and his wife in these years. He therefore drew his readers back to the immediate post-war years when the experiences he described were common, thus stoking the memory of post-war grievances. ${ }^{34}$

The same crib featured prominently in an article in the nationalist weekly Deutsche

\footnotetext{
32 Kolbenheyer, pp. 381-382.

33 Boa and Palfreyman, p.3.

${ }_{34}$ Kolbenheyer, pp.7-8.
} 
Wochenzeitung of $20^{\text {th }}$ June 1986, which reported that it was exhibited at the official opening of the Sudeten German House in Munich on 14th December 1985. Kolbenheyer's ongoing importance for both the Sudetendeutsche Landsmannschaft and the nationalist newspaper was emphasised. The crib, the article explained, was now one of the most valuable pieces at the Kolbenheyer museum in Geretsried. ${ }^{35}$ Placed outside the Sudeten-German House, it became a relic of the lost Heimat, representing the ordinary in a way that reflected a sentimental attachment to the details of domestic life that provided Sudeten Germans with continuity in the face of change. It also provided a tangible link between those expelled from the region and writers like Kolbenheyer who provided them with literary expression.

Kolbenheyer's descriptions in Sebastian Karst also shed light on a second aspect of his relationship with his hometown, which possibly suggests that his identification with Karlsbad and its citizens became more important to him after 1945. After the Second World War, the Sudeten German community became vital for his livelihood and the republication of his works in the 1950s. It provided a large proportion of the members and several leading figures of the Kolbenheyer Society, which was established in 1951 by his supporters. It was only through their subscriptions and donations that the publication of Sebastian Karst was possible in the first place. In calling on the members of the Kolbenheyer-Society to support the project, a newsletter circulated in July 1956 underlined the importance the Society placed on Kolbenheyer in the era of change and confusion Germany was experiencing at the time:

"The author of "Amor Dei" and "Paracelsus" is alive and yet dead for the spiritual development of his Volk. The groundbreaking thinker [...] is silent amidst the tumult of opinions in these changing times - he would promote the noblest attitudes, offer new spiritual assistance, if his words could only be heard. Our lives will be wasted if we forsake what one of the greatest writers and thinkers of the present has to say. This would be irresponsible with regard to the spiritual development of not only our Volk."36

By 1962, the Kolbenheyer Society had 1,200 members and, according to the Schwäbische Tageblatt, was the second largest literary association in the FRG. ${ }^{37}$ It defined its activities using the same terms Kolbenheyer attached to his writing throughout his life: his writing, he believed, grew out of a responsibility to the German Volk.

\footnotetext{
35 'Kolbenheyer in unserer Zeit' in Deutsche Wochenzeitung, No. 26, 20't June 1986, DLA: Erwin Guido Kolbenheyer: Mappe 8, zur Wirkungsgeschichte.

36 'Kolbenheyer in Not. An seine Freunde!' Rundschreiben der Kolbenheyer Gesellschaft, July 1956 in DLA: Kolbenheyer Mappe 8: Zur Wirkungsgeschichte.

37 'Der Schöpfer der Paracelsusdichtung' in Schwäbische Tageblatt, 14.4.1962.
} 
Kolbenheyer, alongside other völkisch nationalists, continued to feel answerable to the Volk after the War. But in the new context after 1945, he also began to emphasise the importance of his work for the 'civilized world', by which he meant the white, European world, thus creating a European cover for his racist ideas. This was threatened with irrevocable change as a result of the brutality of the war years and the massive upheaval evident afterwards. His continued efforts to assert the importance of his work were influenced to a large extent by the attack to which he felt he had been subjected during his 'denazification' trial held in Munich in October 1948. The verdict sentenced Kolbenheyer to 180 days labour over two years. It also placed a five-year ban on his professional activity, preventing the publication of any of his works until 1953. He nonetheless continued to write in private, Sebastian Karst being one of the substantial outcomes. In addition, half his wealth was confiscated, set at a sum of DM 287,000, and he was placed in Group Two, the second highest category of Nazi criminal. ${ }^{38}$ In his defence before the court, Kolbenheyer stood solidly on völkisch-nationalist ground, protesting his uncompromised honour. In summing up, he emphasised the wider historical significance of his case:

"Those standing in judgement should bear in mind that the court is not operating in this case solely within the sphere of political justice, but above all in an intellectual, historical forum, $[. .$.$] that has international significance. I am$ convinced that the judgement that is pronounced will not be quickly forgotten." ${ }^{39}$

Kolbenheyer was right to believe that the verdict passed by the court would be remembered. Even though it was reduced on appeal, the way in which his trial was conducted and the initial verdict fundamentally informed Kolbenheyer's identity in post-war Germany, gaining him considerable public sympathy. In right-wing and nationalist circles he met with acclaim for emerging with his principles uncompromised, 40 but mainstream German newspapers also continued to condemn the proceedings for the rest of his life and even after his death. The trial was referred to, for example, in the national daily newspaper Die Welt in 1962 as a 'tragi-comedy', while the Mannheimer Morgen described it as a 'farce' in 1978. ${ }^{41}$

\footnotetext{
38 Copy of Kolbenheyer's summing up reproduced by Otto Zerlik and sent to friends and enquirers, including Kolbenheyer's publisher, the Langen-Müller Verlag in Munich. In sending it, Zierlik emphasised the private nature of the document; it was not, he stated, for public distribution. In DLA: Otto Zierlik to Albert Langen - Georg Müller Verlag München, 1948-1949.

39 Ibid.

40 Eberhard Fritsch, 'Der Prozess Kolbenheyer' in Der Weg - Monatshefte zur Kulturpflege und zum Ausbau, Buenos Aires, July 1949.

41 'Seine Zeit machte ihn gefährlich: Zum Tode Erwin Guido Kolbenheyers' in Die Welt, 16.4.1962;
} 


\section{Kolbenheyer's reception in 1950s West Germany}

Assessing the readership of a given work or writer is a difficult task. Nonetheless, the success of völkisch-nationalist literature was noted by some commentators at the time. In 1962, for example, Walter Laqueur contested the tendency of German academics and intellectuals in the 1950s to consign the völkisch-nationalist writers whose names were linked to the Third Reich to oblivion, commenting:

"Some of them are apparently more widely printed and, presumably, read than even the better-known contemporary writers of the 'democratic-liberal' camps. True enough, their books are not widely discussed, and they certainly are of no interest to the literary avant-garde, but they have their faithful public, a fact that is usually ignored by the literary critics." 42

The large editions of their works in the 1950s also suggest that a demand for their books continued to exist in Germany. ${ }^{43}$ Hans Sarkowicz estimates, for example, that only one-sixth of the recipients of literary prizes, honours and awards under the supervision of Goebbels' Reich Chamber of Literature between 1933 and 1945 published nothing at all after the War. ${ }^{4}$

Kolbenheyer received the last of twelve literary prizes he was awarded during his career in the post-war era. In 1958 he was presented with the Sudetendeutschen Kulturpreis by the Sudetendeutschen Landsmannschaft, a conservative group representing the ethnic Germans expelled from Czechoslavakia after the War. Sarkowicz cites the award as evidence of the relationships which expellee organisations cultivated with authors of nationalist backgrounds. ${ }^{45} \mathrm{He}$ argues, however, that the importance of these relationships diminished in the early 1960s, basing his argument in part on the apparent absence of a representative of the Sudetendeutsche Landsmannschaft at Kolbenheyer's funeral in 1962.46 Nonetheless a letter from another Sudeten writer, Wilhelm Pleyer, to the Landsmannschaft supports a different conclusion. Pleyer notes that an official from the organisation's

\footnotetext{
'Prophet der deutschen Innerlichkeit' in Mannheimer Morgen 31.12.1978/1.1.1979.

42 Quoted by Stefan Busch, “Und gestern, da hörte uns Deutschland”. NS Autoren in der

Bundesrepublik. Kontinuität und Diskontinuität bei Friedrich Griese, Werner Beumelburg, Eberhard Wolfgang Möller und Kurt Ziesel, Würzburg, 1998, p. 9.

43 Busch p.17. See also Hans Sarkowicz, 'Die litarischen Apologeten des Dritten Reiches zur Rezeption der vom Nationalsozialismus geförderten Autoren nach 1945' in Jörg Thunecke, Leid der Worte. Panorama des literarischen Nationalsozialismus, Bonn, 1987, pp. 435-459, here pp. 436-437.

44 Hans Sarkowicz, 'Die litarischen Apologeten des Dritten Reiches,' p. 436.

45 Hans Sarkowicz, 'Vom "Kahlschlag” keine Spur. Anmerkungen zum Umgang mit der Heimatliteratur des "Dritten Reiches" in der Bundesrepublik Deutschland' in Horst Bienek (ed.), Heimat. Neue Erkundgungen eines alten Themas (Munich / Vienna, 1985), pp.62-72; here p. 66.

46 Hans Sarkowicz, 'Vom “Kahlschlag” keine Spur,' p. 66.
} 
cultural office, Dr. Pfluger had in fact been in attendance at the funeral on behalf of the organisation. ${ }^{47}$ The idea that negative publicity attracted by the award caused the Sudetendeutsche Landsmannschaft to distance itself from Kolbenheyer is further undermined by an article published in the organisation's newspaper, the Sudetendeutsche Zeitung, in 1999. Here the reporter recalled meeting Kolbenheyer

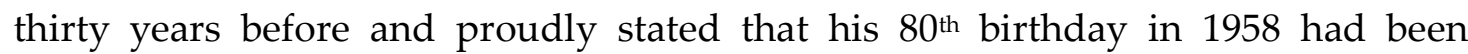
forgotten by all but the Sudetendeutsche Landsmannschaft. ${ }^{48}$

In fact, Kolbenheyer's $80^{\text {th }}$ birthday was all but forgotten. Many of his admirers used the opportunity to celebrate his work, not just as a representative of Sudeten Germans but of the German nation as a whole. The Heimatverband der Karlsbader, an organisation representing expelled citizens of Kolbenheyer's native town of Karlsbad, presented him with the Josef-Hoffmann-Shield during the Karlsbad Week held in Wiesbaden in 1958. Speaking before 2,000 people, the organisation's spokesman praised Kolbenheyer for representing the purest form of the Goethean tradition and the true German Geist, or spirit, the like of which Karlsbad had never before produced. Kolbenheyer attended the ceremony in person to receive the honour. ${ }^{49}$ He was similarly celebrated in Munich, where the literary historian Professor Koch, one of Kolbenheyer's most constant supporters in the post-war years, and the völkisch writer Hermann Burte spoke in his honour. In Vienna, for Kolbenheyer a German city and his second Heimat, he found a warm welcome at a celebration in the Burgtheater. ${ }^{50}$

A number of provincial newspapers likewise took the opportunity offered by Kolbenheyer's $80^{\text {th }}$ birthday to discuss his literary accomplishments. The articles demonstrate the tension between confrontation and avoidance of the Nazi past discussed previously, as they refer to the years between 1933 and 1945 in order to prove that Kolbenheyer remained independent of the National Socialist ideology. The Schwarzwälder Bote provided a typical example: "Whatever one has to say to about Kolbenheyer, the man or the work, all his skill [Geschick] is determined by his Karlsbad background." True to Kolbenheyer's own ideas of 'Parakosmos' - a combination of an individual's hereditary characteristics and the environment in

\footnotetext{
47 Pleyer to National Board of the Sudetendeutschen Landsmannschaft, 6.8.1971 in DLA: Nachlaß Pleyer - Pleyer an die Sudetendeutsche Landsmannschaft.

48 'Vor dreißig Jahren Begegnung mit Erwin Guido Kolbenheyer' in Sudetendeutsche Zeitung, 2.5.1999.

49 'Karlsbader ehren Kolbenheyer und Klemm' in Ludwigsburger Kreiszeitung, 1.10.1958.

50 Wilhelm Pleyer, Hans Grimm, E.G. Kolbenheyer, Will Vesper. Gedenkrede, Munich \& Stuttgart, 1962, p. 13. On Kolbenheyer's reception in Austria during the 1950s see also the fifteenth newsletter of the Kolbenheyer-Society, May 1958 in DLA: Kolbenheyer - Wirkungsgeschichte, and Kolbenheyer to Grimm 9.5.1958 in DLA: Nachlaß Grimm - Kolbenheyer to Grimm, 1946-1959.
} 
which he or she grows up ${ }^{51}$ - the newspaper emphasised that Kolbenheyer's early years in Karlsbad represented a youth spent in an embattled territory, causing his deep feeling for 'Germanness'. Similarly, in line with the intellectual environment of the early twentieth century, Kolbenheyer had turned to biology to provide the foundation for his writing. Hitler and his followers had later claimed biological thinking - völkisch ideology - for themselves, and thus Kolbenheyer had been counted as one of them whether he liked it or not. The article concludes:

"The independent roots and internal logic of Kolbenheyer's writing are beyond doubt. Since Stifter and his 'Witko', since Raabe and his historical novels, no writer in the German language has drawn so seriously on images and myths from the German past." 52

Separating the actions of the Nazis from those of the people was a common defence mechanism. The Germans were not responsible for the dishonour brought on them by the Nazis, and Kolbenheyer should not be blamed because some of his admirers in the Propaganda Ministry had put his name forward for prizes and honours in the Third Reich. The call for an 'objective' judgement of Kolbenheyer in the same article is an example of the way in which confrontation of the Nazi past was avoided in the 1950s, and evidence of the extent to which pre-1945 mentalities lingered, not only among expellee groups and völkisch-nationalists, but in parts of the general population in the FRG. ${ }^{53}$ Nonetheless, contrary to the sentiments expressed here, he was not as 'isolated' as his detractors hoped and his supporters feared. He still attracted attention at the end of the 1950s and the idea that regional origins combined with racial inheritance shaped the individual remained commonplace. The belief in 'Germanness', often combined with resentment that it had been abused by the Nazis, was a widely-shared sentiment in the early years of the FRG.

\section{Conclusion}

Kolbenheyer successfully revived his career after the Second World War. Enough support was found by the Kolbenheyer-Society to publish his entire catalogue of poetry, drama and fiction. He also received steady attention in the press throughout the 1950s and beyond that served to maintain public interest in his work. The receptiveness to his ideas, evident in provincial newspapers in particular, strongly suggests the existence of a substantial readership that was unwilling to address the negative legacy of the Nazi past. Interest in his work was also aided by the recognition he received from Sudeten German organisations. Their members shared

\footnotetext{
51 See for example, Kolbenheyer, Sebastian Karst, Vol. II, pp. 7-8.

52 Otto Karl Ewald, 'Ein Dichter in der Isolierung' in Schwarzwälder Bote, 30.12.1958.

53 Ewald.
} 
Kolbenheyer's nostalgia for a lost Heimat. This became intrinsic to the expellee identity that emerged in post-war Germany. In the 1950s, the concept of Heimat was bound to the experience of German suffering; imagined simplicity, security and familiarity provided a stark contrast to the horrors of expulsion and the challenge of integrating into post-war society. Expellees therefore expressed their grievances without engaging in a closer examination of the Nazi background to their hardships.

Kolbenheyer also continued to provide a bridge between Sudeten identity and German national identity, as he had done before the War. His efforts to revive and adapt völkisch-nationalism for post-Nazi society offered ideological continuity between the pre-war national struggle of Sudeten Germans against the Czech authorities and their post-war efforts to rebuild their lives in a divided Germany. His work also resonated with broader sections of society in West Germany that were likewise seeking continuity and familiarity in the face of social change. Kolbenheyer's post-war circumstances, described in his writing, expressed widely held grievances. Moreover, through his conviction that he was answerable only to the German Volk he communicated accountability to a cause beyond political regimes and occupying powers and exacerbated antagonism against the perceived 'Americanisation' of German culture. As a significant figure in the fight to resist cultural change, he contributed to the tension between the confrontation of the history of the Third Reich and the desire to avoid uncomfortable memories that characterised the early years of the FRG. 